\title{
EFFET DU MODE DE CONSERVATION D'UN MAÏS IMMATURE SUR L'UTILISATION DE SES GLUCIDES ET DE SON AZOTE PAR LE PORC EN FINITION
}

\author{
L. P. BORGIDA et J. DELORT-LAVAL \\ Laboratoire de Recherches sur la Conservation et l'Efficacité des Aliments, \\ Centre national de Recherches zootechniques, I.N.R.A., \\ 78 - Jouy-en-Josas
}

\section{RÉSUMÉ}

La maturité parfois tardive ou incomplète du maïs rend souvent nécessaire un traitement de conservation du grain humide ou son séchage. Ces deux traitements de l'épi et des spathes de maïs ont été comparés par la méthode des bilans, sur huit porcs mâles en finition (50-9o kg).

La rétention azotée obtenue à partir de régimes isoazotés à base de maïs et de soja supplémenté en méthionine est bien meilleure avec le maïs déshydraté $(52,9 \mathrm{p}$. Ioo) qu'avec l'ensilage $(36,9)$. Il en va de mème pour les coefficients d'utilisation pratique de l'azote des 2 régimes $(39,5$ vs 29,4$)$.

L'utilisation digestive des principaux composants du maïs distribué seul est meilleure pour l'ensilage que pour le produit déshydraté (M. azotées : 71 , o vs 56 ,o ; ENA : 84,3 vs 81,$7 ;$ UF/kg : 0,88 vs $0,8 \mathrm{r}$ ).

L'analyse des contenus digestifs de porcs de $90 \mathrm{~kg}$ abattus après un repas test confirme que l'amidon du régime déshydraté transite plus rapidement dans le tractus digestif et que sa digestion y est moins rapide et moins complete que celle de l'anidon du maïs ensilé.

\section{SUMMARY}

\section{EFFECT OF THE CONSERVATION METHOD OF IMMATURE MAIZE UPON THE UTILIZATION OF ITS GLUCIDES AND PROTEINS BY THE FINISHING PIG}

The late or incomplete maturity of maize often necessitates a conservation treatment of the humid grain or drying of the latter. These two treatments of the ear or shuck of maize were compared by means of the balance method using eight finishing male pigs $(50-90 \mathrm{~kg})$.

Nitrogen retention obtained from isonitrogenous diets containing maize and methionine supplemented soybean is much better with dehydrated maize (52.9 p. Ioo) than with silage $(36.9$ p. Ioo). The same holds true in respect of the protein utilization coefficients of the 2 diets $(39.5$ vs 29.4).

The digestive utilization of the main components of maize, distributed alone, is higher for the silage than for the dehydrated product (NM 71.0 vs $56.0 ; \mathrm{NFE} 84.3 \mathrm{vs} 81.7 ; \mathrm{FU} / \mathrm{kg}: 0.88 \mathrm{vs}$ $0.8 \mathrm{r})$.

The analysis of the digestive contents of pigs slaughtered at go $\mathrm{kg}$ after a test meal confirmes that the starch of the dehydrated diet passes more rapidly through the digestive tract and that its digestion is slowlier and less complete than in the case of starch of maize silage. 